\title{
Recent Advances and Remaining Uncertainties in Resolving Past and Future Climate Effects on Global Fire Activity
}

\author{
A. Park Williams ${ }^{1}$. John T. Abatzoglou ${ }^{2}$
}

Published online: 9 February 2016

(C) Springer International Publishing AG 2016

\begin{abstract}
Fire is an integral component of the Earth system that will critically affect how terrestrial carbon budgets and living systems respond to climate change. Paleo and observational records document robust positive relationships between fire activity and aridity in many parts of the world on interannual to millennial timescales. Observed increases in fire activity and aridity in many areas over the past several decades motivate curiosity as to the degree to which anthropogenic climate change will alter global fire regimes and subsequently Earth's terrestrial biosphere. Importantly, fire responses to warming are not ubiquitous and effects by humans, fuels, and nontemperature climate variables are also apparent in both paleo and observational datasets. The complicated and interactive relationships among these variables necessitate quantitative modeling to better understand future fire responses to global change. Macro-scale fire models exhibit a wide spectrum of complexity. Correlation-based models are inherently superior at representing the current global mean distribution of fire activity but future projections developed from these models cannot account for important processes such as $\mathrm{CO}_{2}$ fertilization and vegetation response after extreme events. Process-based models address some of these limitations by explicitly modeling vegetation dynamics, but this requires false assumptions about processes that are not yet well understood. Continued
\end{abstract}

This article is part of the Topical Collection on Extreme Events

A. Park Williams

williams@1deo.columbia.edu

1 Lamont-Doherty Earth Observatory, Columbia University, 61 Rt 9W, Palisades, NY 10964, USA

2 Department of Geography, University of Idaho, Moscow 875 Perimeter Dr., Moscow, ID 83844, USA empirical evaluation of interactions between fire, vegetation, climate, and humans, and resultant improvements to both correlation- and process-based macro-fire models, are mandatory to better understand the past and future of the Earth system.

Keywords Fire $\cdot$ Climate change $\cdot$ Warming $\cdot$ Paleofire $\cdot$ Fire statistical analysis $\cdot$ Fire modeling

\section{Introduction}

Fire is fundamentally interwoven within the Earth system as a forcing on, and responder to, vegetation, atmospheric composition, climate, and human activities [1-4]. Charcoal deposits preserved in ancient sediments indicate that fire emerged in tandem with terrestrial plant life approximately 420 million years ago [5] and that fire activity varies as a result of changes in climate and vegetation across a wide range of temporal and spatial scales $\left[6^{\bullet}\right.$, 7]. Climate and fire may alter vegetation characteristics in tandem or independently and altered vegetation in turn feeds back to alter climate and fire $[1,6 \bullet]$. Further, fire, climate, and vegetation can all affect biotic agents such as pests (e.g., bark beetles), seed distributors (e.g., birds), or humans in ways that feed back to affect fire regimes [3]. Humans also manipulate fire directly by introducing ignitions and either suppressing or promoting fire spread $[8,9]$. Approximately $2.0 \mathrm{Pg} \mathrm{year}^{-1}$ of carbon have been emitted by global wildland fire (natural- and human-caused fires) in recent decades [10], significant relative to the nearly 10 Pg year ${ }^{-1}$ currently emitted by the burning of fossil fuels [11]. While much of this carbon is re-assimilated into post-fire regrowth, approximately $23 \%$ of fire emissions are attributed to tropical deforestation that is not likely to be balanced by full regrowth [10] and thus constitutes a source of atmospheric carbon [e.g., 12, 13]. 
Projections of the response of global fire activity (e.g., fire frequency, area, and severity) to anthropogenic climate change generally indicate increases due to warming, but with much spatial variability [14]. Thus far, warming-related increases in fire activity since 1900 have been observed in the western USA in the last half-century [15], but this followed suppression-driven decreases in the first half of the twentieth century [16]. Globally, fire activity potentially decreased throughout the twentieth century due to human activities, but with compensating increases in tropical areas since the 1960s associated with deforestation [17].

Recently, fire's potential interactions with climate change have gained global attention due in part to extreme "megafire" events that have corresponded with extreme droughts [18], including those across Southeast Asia during the 1997/ 1998 and 2015/2016 El Niño events [19-21], Australia in 2009 [22], Russia in 2010 [23, 24], Amazonia in 2010 [25], and the southwestern USA in 2011 [26]. Although these examples were synchronous with drought conditions, which may be intensified by anthropogenic climate change [e.g., 27], other human effects have also been important. Many of the fires in Southeast Asia, Australia, and the USA were ignited by humans or by man-made infrastructure (e.g., downed power lines). Land management also affected many of these fires. For example, some of the longest-lasting Russian fires in 2010 were promoted by draining and drying of peatlands [28, 29], and a century of fire suppression has led to fuel build-up in the western USA forests [1].

The complex interconnections among fire, climate, vegetation, and humans [e.g., 30] make it challenging to distinguish cause and effect and understand how future changes in climate and human activities will affect fire activity on regional to global scales. Reliable fire projections could guide policy decisions regarding sustainable resource management and provide insight regarding future changes in the terrestrial carbon balance and resultant climate change [31•, 32-34]. Major strides have been made in the understanding of fire regimes and climate-fire relationships in the past decade, thanks in large part to a global satellite-based record of fire activity [35] that allows for robust characterization of fire responses to a wide variety of climate- and land-cover types [e.g., 8,31 , 32, 36-38]. Here, we attempt to distill recent advances in scientific knowledge made in the last 2 to 3 years on fireclimate-vegetation-human interactions to better understand how regional-to-global fire regimes may change throughout this century and where dominant uncertainties remain.

\section{Empirical Lessons}

There are many ways to empirically evaluate the relationships between climate and fire. We first survey recent advances in the evaluation of these relationships on relatively long timescales from paleo-reconstructions of fire, climate, fuels, and human activities. We then survey advances made from more recent observational records.

\section{Paleo Studies}

\section{Ice Cores}

Ice cores store information about past fire activity because gases and deposited particulate matter are preserved within snow as it is buried and packed into ice. Although icecore collections are limited geographically, their strength as proxies is that they can extend back tens or hundreds of thousands of years and the information they store is an integration of processes occurring on continental to global scales. Ice cores from Greenland show that millennial periods of increased temperature during the last glacial cycle coincided with rapid increases in North American fire activity due to the warming influence on fuels via changes in physiology and/or distribution (e.g., transition from tundra to forest) [39]. During the past two millennia, the Greenland ice core reconstruction indicates close centennial-scale correspondence between boreal forest fire activity, temperature, and drought [40], though human burning activities (land clearance) in temperate Europe may also be evident in these cores [41]. In the Southern Hemisphere, an Antarctic ice core indicates reduced fire activity in the past several centuries, likely due to reduced burning of savannas in South America, southern Africa, and Australia as a result of human-induced landscape fragmentation [42].

\section{Charcoal Sediments}

Charcoal-based reconstructions can be collected from many locations globally and combined to represent a range of spatial scales over hundreds to several thousands of years. Marlon et al. [6•] used 703 charcoal records from across the globe to examine the variability in regional-to-continental fire activity during the Holocene. Consistent with ice-core results, Marlon et al. [6•] find that fire activity increased in Europe and North America throughout the early Holocene due to widespread reorganizations of ecosystems following the last glacial period. This early Holocene effect of climate on fire via ecosystem changes may have been most dominant at relatively high latitudes where boreal conifer-dominated forests established after ice sheets receded [43, 44]. Some recent charcoal studies have highlighted further complexity to the relationship between high-latitude fire and warming, however, as warming in southern boreal zones appears to promote less flammable broadleaf forests $[45,46]$. 
During the late Holocene, charcoal records highlight the continued dominance of climate over fire activity at regional to continental scales. Warming during the Medieval Climate Anomaly ( 900-1300 AD), for example, corresponded with increased charcoal-derived fire activity in boreal Alaska [44, 47], the Pacific Northwest of North America [48], and the central Rocky Mountains [49], though in that case fire activity decreased while temperatures were still high, likely indicating a fuel limitation. Subsequent decreases in the global fire activity at the onset of the Little Ice Age ( 1500-1850 AD) are again consistent with the generally positive correlation between temperature and fire activity $[6 \bullet, 44,50]$, but this decrease in North American fire activity also coincided with the massive decline of Native American populations, who undoubtedly affected fire regimes prior to European arrival [e.g., 51].

While humans are known to have affected historical fire regimes, these effects are difficult to detect on the broad spatial scales often evaluated in charcoal-based studies because human effects have been highly variable in time and space [e.g., 52]. For example, Marlon et al. [6•] indicate that increasing population in Europe over the past several thousand years corresponded to a widespread increase in European burning during $\sim 4$ to $2 \mathrm{kya}$ (also supported by ice core evidence [41]) and then to declines in burning over the past 2 kya [6॰]. The increases and subsequent decreases in European burning over the past $\sim 4$ ky may have corresponded to anthropogenic clearing of forest and subsequent fuel limitation [e.g., 53-55], exemplifying the opposing influences that humans can have on fire regimes and why it may be difficult to infer direct human effects from a comparison of population data to fire reconstructions [e.g., 6•]. Human impacts on the environment have become increasingly unmistakable during the past century, with increases in fire activity in some regions (e.g., Pacific Islands, central Europe, and Australia) due to human ignitions and/or land clearing and decreases in fire activity in other regions (e.g., western USA and sub-Saharan Africa) due to land-use change and/or fire suppression. Collectively, such changes can fundamentally alter fire-climate relationships through time and can confound the attribution of changes in fire activity.

\section{Tree Rings}

Fire scars on trees are often preserved visibly within tree-ring sequences [56], fueling the recent archival of many tree-ringbased fire reconstructions within an international paleofire database. In the western USA, tree-ring reconstructions indicate a strong pre-European correspondence between wildfire and drought [e.g., 57-66]. The high temporal precision of tree-ring-based reconstructions is not possible with charcoal or ice core records and can elucidate more nuanced climate effects such as the tendency in relatively dry areas for high fire activity to be preceded by anomalously wet years, which promote fuel growth [e.g., 67] and fire spread [65]. Treering-based fire reconstructions also indicate a substantial reduction in fire activity during the first half of the twentieth century throughout the western USA [e.g., 63, 68]. The dramatic early twentieth century reductions in fire activity in the western USA and elsewhere [e.g., 69] is concerning because fire suppression has caused many areas to accumulate a "fire deficit," where increased fuel loads due to lack of fire have increased the likelihood of unusually high fire activity in the future $[1,70,71]$. The fire deficit across the western USA is heterogeneous, with the largest deficits in lower-elevation dry forests where suppression priorities are highest. There is less evidence of a fire deficit in mesic, higher elevation, or remote forests [72]. Tree-ring fire reconstructions and plot data indicate that suppression-induced fire deficit in the western USA has led to increased fire severity [73] and changes in species composition, which in turn affect fire regimes [74]. Notably, one fire-free century may not represent a departure from expected undisturbed conditions for some forest types in the western USA [e.g., 75-77], but such a hiatus in fire activity is very uncommon for other forest types [e.g., 59].

Warming promotes fire via the exponential effect of temperature on the atmosphere's vapor-pressure deficit [e.g., 78], which enhances the atmosphere's evapotranspiration potential (PET) and depletes fuel moisture. This link to temperature appears particularly strong in boreal coniferous forests [e.g., $79,80]$, though tree-ring burn scars from boreal Canada also indicate that warming-induced increases in fire activity have already become self-regulating in some areas by creating large swaths of younger, lower biomass forest that effectively act as fuel breaks [81]. The legacy effects of past fire on fuel characteristics impact subsequent fire potential and are important to consider in the development of projections of future fire activity. Paleo data provide critical insight into the functioning of relatively low-frequency (decadal to centennial) processes that are not possible to observe.

\section{Observational Studies}

Studies that collect and/or utilize observational data aim to better understand the drivers of relatively short-term variations and trends in fire activity with a higher precision than is possible through paleo approaches. Global analyses of macro-fire activity are limited to the use of recent satellite observations of burned area and are therefore too short to put observed trends or anomalies into a historical context. Regional or countrywide observational records can extend further back (several decades to a century) but often involve combining numerous datasets and correcting for biases associated with inhomogeneities [e.g., 16, 82]. Among observational studies, burned area and fire frequency are the most extensively examined, as fire impacts and severity (e.g., tree mortality and carbon emissions) remain challenging to accurately quantify [83]. 
An observational fire dataset that combines unique temporal depth, consistency, and spatial extent is the satellitederived Monitoring Trends in Burn Severity (MTBS) product, which extends back to 1984 for the USA [84]. MTBS only represents large fires and excludes the vast majority of reported fires. However, MTBS fires larger than 404 ha accounted for over $92 \%$ of forest area burned in the western USA based on the comprehensive wildfire database developed by Short [85]. Thus, the MTBS dataset is of limited use for evaluations of fire frequency or spatial distribution but it is well suited for studies of area burned (see more description of MTBS strengths and limitations in a review by Short [86]). Dennison et al. [87] used MTBS data to document significant increases in the frequency and area of large fires in the western USA during 1984-2011. These trends were spatially heterogeneous, with the greatest increases occurring in Rocky Mountain and Southwestern USA forests (documented with greater detail in [88]). Figure 1a combines the MTBS dataset with a more up-to-date but shorter satellite-derived burned area product [89] to show that western USA burned forest area increased significantly $(P<0.01)$, and potentially exponentially, during 1984-2015. While the annual western USA forestfire areas of the past $\sim 15$ years have been high compared to those of the latter half of the twentieth century, they may still be lower than pre-twentieth century levels in many areas due to fire suppression [e.g., 76, 90].

Attribution of recent trends in area burned is challenging due to co-occurrences of trends in climate, fuels, and human activities. An advantage, however, is that climate is more temporally variable than other co-occurring processes such as land and fire management. Several studies have noted a strong positive correlation between temperature and fire activity (e.g., burned area and fire frequency) across large parts of the USA [88, 91-98]. However, observational studies generally find stronger correlations between fire activity and climate variables that more comprehensively represent potential flammability such as PET or fuel moisture than temperature alone [88, 91, 93, 99]. Precipitation has a more complex relationship with fire activity [e.g., 88], as it can enhance fire potential in fuel-limited fire regimes by promoting fuel growth and also suppress fire potential by reducing flammability.

In Fig. 1b, we demonstrate a preliminary attribution effort, showing that the significant increase in western continental USA forest-fire area during 1984-2015 has corresponded to a significant warming-driven increase in annual PET. The record of burned forest area in Fig. 1a and the PET record in Fig. 1b correlate well $(r=0.88)$, and this correlation remains strong $(r=0.82)$ after both linear trends are removed (Fig. 1c), lending support to a mechanistic relationship. Assuming the interannual relationship shown in Fig. 1c is consistent at the decadal scale, the positive trend in PET accounts for $\sim 78 \%$ of the positive trend in burned area since 1984. Importantly,
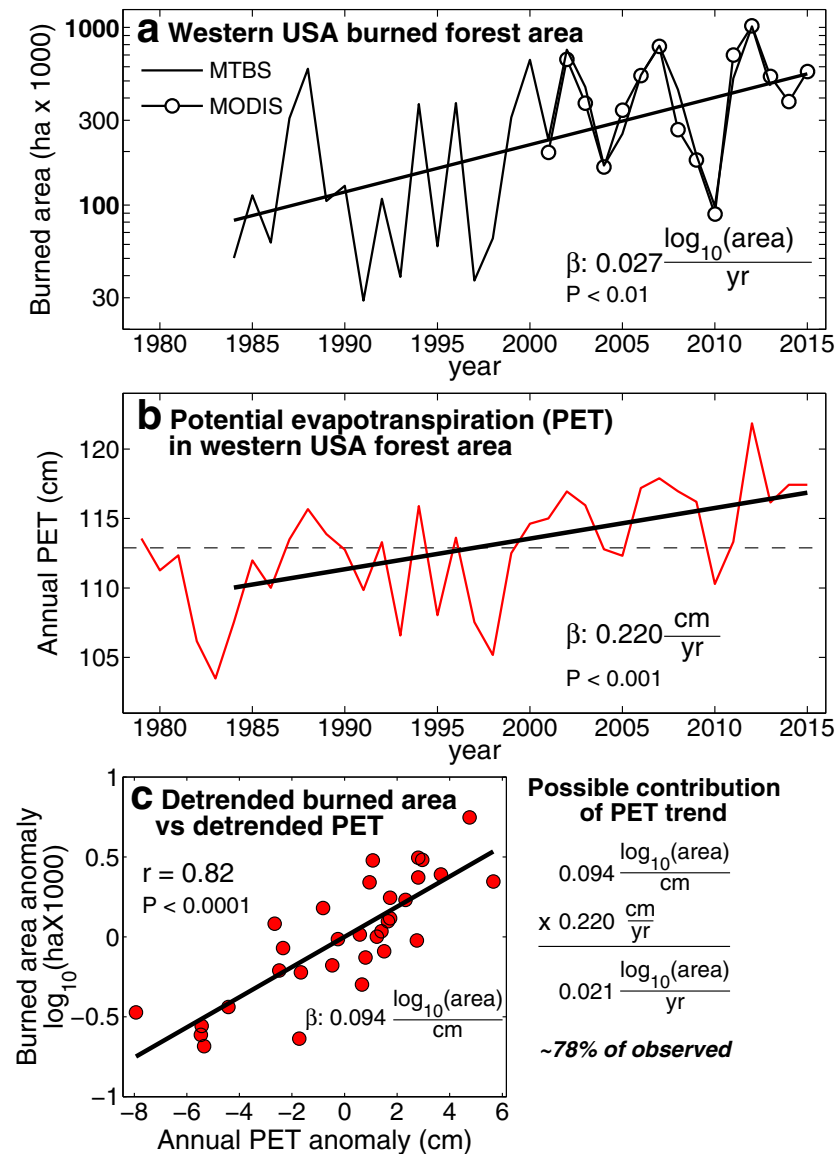

Fig. 1 Annual burned area and atmospheric moisture demand in western continental USA forests. a Annual burned area derived from satellite records from 1984 to 2015. The MTBS record is extended through 2014 and 2015 with MODIS. b Annual potential evapotranspiration (PET) calculated from the Penman-Monteith equation [e.g., 27] from 1979 to 2015. c Scatter plot of the time series in (a and b) after linear trends during 1984-2015 are removed. Math to the right calculates the possible contribution of the PET trend to the burned-area trend if the interannual covariability of these variables also applies to trends. Western USA forest in this analysis is any continental USA area west of $100^{\circ} \mathrm{W}$ that is defined as forest or woodland by the Environmental Site Potential land-cover dataset from the LANDFIRE database (http://www. landfire.gov/)

burned area is affected by other climate processes and also by non-climate factors, and work still needs to be done to parse apart the roles of anthropogenic warming and natural temperature variability during this period [e.g., 27]. Nonetheless, the strength of the observed interannual relationship between PET and forest-fire area and the co-occurring positive trends suggest that (1) continued warming will promote continued increases in western USA forest-fire area while fuels are not limiting, consistent with previous empirical evaluations [e.g., 15, 92], and (2) other processes besides increased PET have also contributed to the increase in the western US forest fire area and will continue to do so.

Weather conditions are also critical drivers of fire activity, and it is generally the co-occurrence of optimal fire weather 
(hot, low humidity, and windy) with already dry fuels due to anomalously dry climate that promotes fire spread [96, 100-105]. Jolly et al. [102•] show that the global mean annual duration of the fire-weather season increased by approximately $18 \%$ during 1979-2013 and the global area experiencing long fire-weather seasons more than doubled during this time. This global evaluation of observed fire-weather trends and previous evaluations at regional scales [e.g., 106] does not explicitly separate the effects of anthropogenic climate change from those associated with natural variability and that is a next step toward more accurately anticipating future changes in fire weather.

Should continued warming lead to continued increases in fire potential in the western USA and elsewhere? This question is difficult to answer based on fire-climate relationships such as that shown in Fig. 1 that are derived from temporal covariation with a single independent variable during the short observational time period. Using a uniquely long burned-area record for 1902-2008 from the northern Rocky Mountains, Higuera et al. [107•] showed empirical fire-climate relationships to be non-stationary in time. These non-stationarities were posited to arise as a result of aggressive and successful suppression efforts during the mid-twentieth century when climatic conditions favored suppression, thus contributing to increased fuel density. The subsequent reemergence of more fire-favorable climate over the last three decades coincided with the legacy of suppression over previous decades and resulted in the strongest fire-climate relationship of the record. Therefore, statistical models developed using recent fire-climate relationships significantly over predict the area burned in the northern Rocky Mountains during the early-to-mid twentieth century. A similar result was found for the Mediterranean, where increases in fire activity and the strength of fire-climate relationships beginning in the 1970s were associated with fuel build-up due to rural depopulation [108]. Importantly, empirically derived instabilities in fire-climate relationships do not imply instabilities in the actual processes that govern fire. They instead highlight the importance of fuel characteristics and human activities as modulators of fire response to climate variability as well as the importance of sampling from a broad range of climates and biophysical conditions when empirically evaluating fire-climate relationships.

Although observational records are often too short to reliably quantify the interacting effects of the many drivers of temporal variations of fire activity in a given area, the laws that govern the fire frequency and size appear to be ubiquitous globally [109]. This suggests that if we can learn the laws that govern spatial variability in the mean state of fire across the globe we should be able to apply those lessons to estimate how fire should change in response to temporal changes in the governing factors [e.g., $8,31 \bullet, 32,110,111 \bullet, 112]$. This approach allows for space-for-time inferences, where the interactive effects of climate/weather, land management, and fuel characteristics may be detectable spatially even though the impacts of these processes often play out too slowly to be accurately depicted in observational studies.

Recent advancements in this realm of pyrogeographic statistics have largely been motivated by the potential for improving the representation of fire in Earth system models [111•]. Pausas and Ribiero [113] built upon the foundational global pyrogeographic studies described above to detect a statistically significant hump-like relationship between vegetation productivity and fire activity that had been previously hypothesized. An improved understanding of the relationship between fire activity and vegetation productivity (also noted previously [e.g., 8, 32, 114]) marks an important advance beyond studies that treat mean climatology as a single direct driver of fire regimes. Importantly, many studies do not distinguish among types of fire regimes (e.g., crown fire versus surface fire), which are dependent on vegetation type instead of productivity only. Archibald et al. [115] have begun to address this issue using climate predictors to estimate the probability that a given fire regime, defined by fire size, frequency, intensity, season, and extent, exists in a given location.

Human activities can also cause state-changes to fuel and fire regimes. Pyrogeographic studies have made substantial recent advances in the quantification of how human demographic factors such as population density and socioeconomics affect fire activity [e.g., 116-122]. An emerging consensus is that human population density and wealth both have net negative impacts on burned area due to fire suppression and fuel fragmentation. These negative forcings appear to generally outweigh the positive effects of anthropogenic ignitions and fire use except for among very low population densities.

\section{Fire Modeling and Future Projections}

Fire modeling is done at a range of scales, from physics-based models with high spatial and temporal resolution [e.g., 123-125] to more highly parameterized macro-scale models operated at the larger scales of interest for this review. These macro-scale models apply a range of approaches, from empirically-derived statistical modeling to more processbased approaches that combine mechanistic modeling with empirical formulations.

Empirically-derived statistical modeling incorporates observed relationships between fire activity and potential causal factors to infer how fire activity would respond to hypothetical changes in the causal factors [e.g., 38, 110, 111•, 126]. Projections of fire activity made solely by applying empirically derived climate-fire relationships (such as that in Fig. 1) to projections of climate change generally suggest enhanced fire activity for most regions globally as a result of increased fire- 
season aridity [e.g., 31•, 127-135], despite the fact that these increases will clearly be tempered in some regions as fuels become limiting [e.g., 136]. In other regions where fire-climate relationships have historically been difficult to detect, warming and other climatic or land-management changes may lead to the emergence of these relationships.

The complex interactions between the effects of climate, fuels, and humans on fire activity give rise to the need for complex modeling approaches that can account for these interactions as many factors simultaneously change and interact in the future. Given the need for many degrees of freedom when building an empirical model that accounts for a variety of interacting factors, the space-for-time approach described in the last section is a tempting method to generate future projections of fire activity [111•]. Indeed, there have now been multiple efforts to force empirical spatially-derived models with future climate data and the projections account for far more complexity than would be the case if temporal fire-climate relationships had been simply extrapolated into the future $[31 \cdot, 32]$. In California, extrapolations of temporal relationships with climate $[97,137]$ imply more acute increases in fire activity than those that holistically consider changes to climate, vegetation, human land use, and fire suppression based on a pyrogeographic modeling framework [138, 139]. Considering Mediterranean biomes globally, Batllori et al. [140] used a pyrogeographic model to demonstrate divergent changes in fire activity resulting from climate change. They found that warming and wetting should cause increases in fire activity while warming and drying should cause decreases in fire activity due to decreases in fuel availability implied by the drying.

While observations from a global domain allow for a robust characterization of the current combined effects of climate, fuel, and human population on fire activity in space, and it follows that these relationships should also apply in time, projections based on current empirical pyrogeographic models generally represent changes in the future mean state because they are developed on temporally averaged data. Thus, these models do not incorporate the effects of climatic sequencing on fuels and fire activity. Given the short period of observations in many parts of the globe, it is difficult or impossible to fully validate the temporal projections made by these spatially derived models. As spatially extensive observational records of fire activity grow longer, it will become increasingly possible to use spatial and temporal variability together to develop empirical pyrogeographic models that can represent higher-frequency variations in time that can be more readily validated [e.g., 141, 142•].

Further, projections of fire activity based only on longterm changes in the mean state of forcing variables may be problematic because they do not explicitly account for the effects of extreme events. This is particularly true for fire regimes with long fire return intervals where landscape flammability can only occur under highly anomalous climatic conditions [143]. Extreme climate events may cause state-shifts in land cover that force fire regimes to diverge, at least temporarily (e.g., years to millennia), from those consistent with the mean climate [e.g., 144]. Indeed, Parisien et al. [142•] found that an empirical model of Canadian fire based on both climatological means and interannual climate variability was able to better account or the self-regulating property of fire [e.g., 81, 145] than a model based only on climatological means. Conversely, fire can lead to vegetation-type conversions that may lead to increased potential for future fire. In the western USA, forest and woodland may be replaced by non-native annual grasses such as cheatgrass (Bromus Tectorum l), which is fire adapted and promotes increased fire frequency and spread [146]. Similarly, Brando et al. [25] observed that enhanced fire due to recent severe droughts in southeastern Amazonia drove type conversions from forest to flammable grass species near forest edges, promoting further fire spread and type conversion. Empirical modeling efforts are now underway to better represent fire-regime shifts in response to climate changes [147, 148].

The above examples of fire-fuel interactions occur at spatial, temporal, or species-specific scales that may be too fine for the large-scale empirical modeling approaches described above. Further, empirical models can only be validated for conditions with empirical precedents. In the future, nonanalog changes in climate, atmospheric $\mathrm{CO}_{2}$, and human population demographics (and technology used to suppress or promote fire) are likely to create conditions not fully represented by empirical models. Non-analog future conditions incentivize the use of process-based models that simultaneously simulate climate, vegetation, and human factors, their interactions, and their effects on fire activity using first principals [149]. Importantly, the "first principles" modeling approach is not free of the empirical modeling approaches described above, as dynamic global vegetation models (DGVMs) and macro-scale fire models are parameterized to optimize agreement with observations. Yang et al. [150, 151•] used observations of climate, human demographics, and atmospheric $\mathrm{CO}_{2}$ to drive a DGVM and an embedded fire module to simulate global fire activity during 1901-2010. In the Yang et al. studies, global burned area declines steadily over the past century primarily due to declines in the tropics and mid latitudes associated with land-use change, deforestation, and fire suppression. This is in agreement with charcoal records [152] but difficult to verify with observations.

Considering the future, Knorr et al. [153•] connected a DGVM with an empirically calibrated fire module to simulate the impacts of changes in climate, atmospheric $\mathrm{CO}_{2}$, and human demographics on regional-to-global fire emissions throughout the twenty-first century. They projected net positive (though highly heterogeneous) trends in global fire 
emissions due to warming (drying of fuel) and increasing $\mathrm{CO}_{2}$ (increased fuel growth), but a compensating net negative effect due to increasing human population. It is important to note that this projection of a net negative human impact is nearly entirely driven by sub-Saharan Africa and the projected human impact is neutral in most regions globally, exemplifying the likely dominance of future trends in African fire on global pyrogenic emissions. Combining the net effects of climate change, increased atmospheric $\mathrm{CO}_{2}$, and local human effects, Knorr et al. [153•] project global fire emissions to remain approximately constant or slightly increase for the rest of this century, and to be unlikely to return to pre-1900s levels by 2100 . Importantly, Knorr et al. [153•] use a single fire model and it has been shown that fire-activity projections are widely variable among models [154], so these results should be viewed as preliminary and as motivation for future efforts of this kind where the spatially explicit, partial contributions of various forcings are examined.

Linking the past to the future using a highly process-based modeling approach, Kelly et al. [155 ${ }^{\circ}$ combined charcoalbased fire reconstructions and other paleoenvironmental data with vegetation-fire modeling to reconstruct carbon dynamics in Alaskan boreal forests since $850 \mathrm{AD}$. They forced a DGVM-fire model with paleoenvironmental reconstructions and show that wildfire has likely been the dominant source of variability in carbon storage within Alaskan boreal forests over the past 1200 years. The simulations also suggest that increased fire frequency since 1950 has led to large carbon losses relative to the historic range of variability. This has critical implications for the future carbon balance of the northern hemisphere boreal zone, where continued increases in fire activity are expected due to rapid warming and limited capacity for suppression by humans [156].

\section{Obsticles Inhibiting Reliable Fire Projections}

Several uncertainties inhibit reliable projection of future regional and global fire activity. Efforts to parameterize and validate regional-to-global fire models are currently constrained by the relatively short duration of high-quality observational records of fire activity. Because the observational record of global fire activity has far more variability in the spatial domain than in the temporal dimension, macro-scale fire models (both empirical and "process-based") are generally parameterized to optimize agreement with a map of mean fire conditions during the period of record. Projections made from such modeling approaches are based on projections of mean predictor conditions with no temporal variability along the way [31•]. In reality, fires occur as discrete events and alter the landscape (e.g., ecological succession, fuel abundance, and connectivity) such that by, say 2050 , a landscape may have a much different fuel structure than that which would be predicted based on the mean climate of 2050 [149]. Errors caused by ignoring legacy effects of specific events are likely to be increasingly averaged out as larger regions are considered, however, because integrative effects of wildfire events are implicit to some degree in correlation-based models. This does not appear to be the case everywhere, however, as mean climate can be very similar for both tropical forest and savanna vegetation cover types [157]. Additionally, the relatively short satellite-based fire record and resultant modeling of long-term mean conditions limits rigorous validation of simulated temporal changes in fire activity. Another source of uncertainty comes from the fact that satellite-based records inherently miss small fires, which may have important contributions to actual burned areas and emissions beyond those calculated from satellite records, particularly in tropical regions [158].

Importantly, empirically-based fire modeling requires the assumption that interactions among predictor variables are fully characterized within the ranges of variability of the observations. This assumption is not entirely valid for vegetation. Increased atmospheric $\mathrm{CO}_{2}$ is projected to lead to changes in vegetation-climate relations by enhancing plant water-use efficiency [159]. Enhanced water use efficiency is projected to allow vegetation biomass to increase in many regions globally, but this process and its interactions with other growth-limiting resources is not fully understood [e.g., 160-164]. Satellite observations of global vegetation greenness do suggest that a positive $\mathrm{CO}_{2}$ effect on vegetation productivity is already underway $[165,166]$ (as well as greening and an extension of the early growing season due to warming [167]) but it is not well understood how added biomass and change in growth timing is affecting vegetation structure [168], which is important for fire intensity and spread. More broadly, it is not well understood how global vegetation systems will respond to climate change even in the absence of physiological $\mathrm{CO}_{2}$ effects, as these responses will be species-, site-, and season-specific and highly dependent on difficult-to-model processes such as plant mortality, insect and pathogen outbreaks, and recovery or succession following disturbances [169-171].

Likewise, it is probably not accurate to assume a constant relationship between humans and fire. In global models, human impact is often approximated as a function of population density, socioeconomics, and perhaps distance from an urban area or road. These impacts are based on an empirical snapshot of the current (or recent) spatial relationships between population density and satellite-derived fire occurrence and size [e.g., 9, 119-122, 138, 172]. In the future, changes in technology and cultural values may have regional-to-global effects on ignitions, suppression practices, and land use that cause deviations from established statistical responses to standard population demographic metrics.

Finally, much uncertainty in the response of fire to climate change is due to uncertainty in climate change itself. Of that 
uncertainty, much is due to uncertainty about future global socioeconomic development, international environmental regulation, and the resultant trajectory of global anthropogenic greenhouse gas emissions [173-175]. Currently, the difference between climate-model projections of warming by $2100 \mathrm{AD}$ for the two most commonly considered greenhouse-gas emission pathways is approximately as large as the uncertainty among climate models for a single emissions pathway [176]. Uncertainties in climate modeling are also important because fuel growth and dry-down, ignition, and fire spread are influenced by difficult-to-model meteorological features such as precipitation amount and variability [177], lightning [178-182], and extremes in boundary-layer wind and vapor-pressure deficit $[26,183]$. Additionally, natural decadal climate variability can cause trends that deviate from projections, adding near-term uncertainty to fire projections even if all other aspects of the Earth system are modeled perfectly.

Projections of future fire activity inherently integrate the uncertainties in projections of several complex and interacting variables. Uncertainties can be partially quantified at a range of scales following the framework of Knorr et al. [153•] where projections are made in a factorial manner to determine the partial contributions of various assumptions to projected changes. As observational records of fire activity and its predictors grow longer, it is critical that models are increasingly validated against the historical temporal variability in observed records, and even in paleo records when possible. More temporal-based modeling may be relatively feasible in the USA, where a Landsat-based record of large fires extends back to 1984 and government records may be used to extend even further. Regardless of datasets used, researchers should maximize degrees of freedom for statistical relationships by designing data-flexible studies that can accommodate updated observational data when they become available.

\section{Conclusions}

The future of wildfire regionally and globally will be affected by changes in climate, atmospheric $\mathrm{CO}_{2}$, fuels, humans, and their complex interactions. Among recent macro-scale fire projections, there is much spatial heterogeneity and the most consistent projection is toward warming-driven increases in high-latitude fire activity. These projections are generally consistent with observational and paleo records of fire and climate, though the coincidence between high-latitude fire and warmth is strongly modulated by vegetation dynamics and is by no means ubiquitous in time or space. Outside of the highlatitudes, compensating forcings from relatively poorly constrained projections of climate changes (particularly precipitation), vegetation changes, and population effects cause much spatial heterogeneity in fire projections. In particular, large uncertainties across fire-prone sub-Saharan Africa due to poorly known fuel responses to climate, $\mathrm{CO}_{2}$, and humans will be important to resolve given the large carbon fluxes from wildfire in that region.

Among macro-scale fire modeling approaches, there is a wide spectrum of complexity that can be incorporated when making projections of the future. There are tradeoffs between relatively simple assumptions of temporally constant vegetation cover, monotonic climate change, and human demographic effects versus more complex incorporation of dynamic vegetation cover, interannual climate variability, human socioeconomic factors, and nuanced fire variables such as fire perimeters and rates of spread. A middle-ground between correlation-based and mechanistically-based models may provide the best current approach for understanding future changes in fire activity. Future efforts should migrate toward enhanced complexity at a prudent rate as observational datasets, physical understanding, and computational capabilities improve [e.g., 149]. To this end, continued work is essential to better understand the first-principals and statistical representations of the complex interactions among climate, meteorology, vegetation, humans, and fire, and this enhanced understanding necessitates enhanced collaboration between empirical and dynamical modelers.

Acknowledgments This work was funded by the Lamont-Doherty Earth Observatory of Columbia University, Columbia University's Center for Climate and Life, the National Aeronautics and Space Administration Terrestrial Ecology Program under award NNX14AJ14G, and the National Science Foundation Hazards SEES Program under award 1520873. Thanks go to two anonymous reviewers who provided helpful and insightful suggestions. Lamont-Doherty publication number 7967.

\section{Compliance with Ethical Standards}

Conflict of Interest On behalf of all authors, the corresponding author states that there is no conflict of interest.

\section{References}

Papers of particular interest, published recently, have been highlighted as:

- Of importance

1. Marlon JR, Bartlein PJ, Gavin DG, Long CJ, Anderson RS, Briles $\mathrm{CE}$, et al. Long-term perspective on wildfires in the western USA. Proc Natl Acad Sci U S A. 2012;109:E535-43. doi:10.1073/pnas. 1112839109.

2. Bowman DMJS, Balch JK, Artaxo P, Bond WJ, Carlson JM, Cochrane MA, et al. Fire in the Earth system. Science. 2009;324:481-4. doi:10.1126/science.1163886. 
3. Bond WJ, Woodward FI, Midgley GF. The global distribution of ecosystems in a world without fire. New Phytol. 2005;165:52538. doi:10.1111/j.1469-8137.2004.01252.x.

4. Goldammer JG. Vegetation fires and global change: challenges for concerted international action. Remagen-Oberwinter: Kessell Publishing House; 2013.

5. Scott AC, Glasspool IJ. The diversification of Paleozoic fire systems and fluctuations in atmospheric oxygen concentration. Proc Natl Acad Sci U S A. 2006;103:10861-5. doi:10.1073/pnas. 0604090103.

6. Marlon JR, Bartlein PJ, Daniau A-L, Harrison SP, Maezumi SY, Power MJ, et al. Global biomass burning: a synthesis and review of Holocene paleofire records and their controls. Quat Sci Rev. 2013;65:5-25. doi:10.1016/j.quascirev.2012.11.029. This study presents a large meta-analysis of global charcoal records and finds that climate was a dominant driver of regional to global fire activity throughout the Holocene.

7. Meyn A, White PS, Buhk C, Jentsch A. Environmental drivers of large, infrequent wildfires: the emerging conceptual model. Prog Phys Geogr. 2007;31:287-312. doi:10.1177/0309133307079365.

8. van der Werf GR, Randerson JT, Giglio L, Gobron N, Dolman AJ. Climate controls on the variability of fires in the tropics and subtropics. Glob Biogeochem Cycles. 2008;22, GB3028. doi:10. 1029/2007GB003122.

9. Kloster S, Mahowald NM, Randerson JT, Lawrence PJ. The impacts of climate, land use, and demography on fires during the 21st century simulated by CLM-CN. Biogeosciences. 2012;9:509-25. doi:10.5194/bg-9-509-2012.

10. van der Werf GR, Randerson JT, Giglio L, Collatz GJ, Mu M, Kasibhatla PS, et al. Global fire emissions and the contribution of deforestation, savanna, forest, agricultural, and peat fires (1997-2009). Atmos Chem Phys. 2010;10:11707-35. doi:10. 5194/acp-10-11707-2010.

11. Ballantyne AP, Alden CB, Miller JB, Tans PP, White JWC. Increase in observed net carbon dioxide uptake by land and oceans during the past 50 years. Nature. 2012;488:70-2. doi:10.1038/ nature11299.

12. Le Quéré C, Raupach MR, Canadell JG, Marland G, Bopp L, Ciais $\mathrm{P}$, et al. Trends in the sources and sinks of carbon dioxide. Nat Geosci. 2009;2:831-6. doi:10.1038/ngeo689.

13. Ward DS, Kloster S, Mahowald NM, Rogers BM, Randerson JT, Hess PG (2012) The changing radiative forcing of fires: global model estimates for past, present and future. Atmos Chem Phys 12. doi:10.5194/acp-12-10857-2012.

14. Flannigan MD, Krawchuk MA, de Groot WJ, Wotton BM, Gowman LM. Implications of changing climate for global wildland fire. Int J Wildland Fire. 2009;18:483-507. doi:10.1071/ WF08187.

15. Westerling AL, Hidalgo HG, Cayan DR, Swetnam TW. Warming and earlier spring increase western US forest wildfire activity. Science. 2006;313:940-3. doi:10.1126/science.1128834.

16. Littell JS, McKenzie D, Peterson DL, Westerling AL. Climate and wildfire area burned in Western US ecoprovinces, 1916-2003. Ecol Appl. 2009;19:1003-21. doi:10.1890/07-1183.1.

17. Mouillot F, Field CB. Fire history and the global carbon budget: a $1^{\circ} \times 1^{\circ}$ fire history reconstruction for the 20th century. Glob Chang Biol. 2005;11:398-420. doi:10.1111/j.1365-2486.2005. 00920.x.

18. Adams MA. Mega-fires, tipping points and ecosystem services: managing forests and woodlands in an uncertain future. For Ecol Manag. 2013;294:250-61. doi:10.1016/j.foreco.2012.11.039.

19. Page SE, Siegert F, Rieley JO, Boehm H-DV, Jaya A, Limin S. The amount of carbon released from peat and forest fires in Indonesia during 1997. Nature. 2002;420:61-5. doi:10.1038/ nature 01131
20. van der Werf GR, Randerson JT, Collatz GJ, Giglio L, Kasibhatla PS, Arellano AF, et al. Continental-scale partitioning of fire emissions during the 1997 to $2001 \mathrm{El} \mathrm{Nino/La} \mathrm{Nina} \mathrm{period.} \mathrm{Science.}$ 2004;303:73-6. doi:10.1126/science.1090753.

21. Cochrane J (2015) Indonesia's Forest Fires Take Toll on Wildlife, Big and Small. The New York Times, 30 October 2015. http:/ www.nytimes.com/2015/10/31/world/asia/indonesia-forest-fireswildlife.html.

22. Cruz MG, Sullivan AL, Gould JS, Sims NC, Bannister AJ, Hollis JJ, et al. Anatomy of a catastrophic wildfire: the Black Saturday Kilmore East fire in Victoria, Australia. For Ecol Manag. 2012;284:269-85. doi:10.1016/j.foreco.2012.02.035.

23. Chubarova N, Nezval Y, Sviridenkov I, Smirnov A, Slutsker I. Smoke aerosol and its radiative effects during extreme fire event over Central Russia in summer 2010. Atmos Meas Tech. 2012;5: 557-68. doi:10.5194/amt-5-557-2012.

24. Konovalov IB, Beekmann M, Kuznetsova IN, Yurova A, Zvyagintsev AM. Atmospheric impacts of the 2010 Russian wildfires: integrating modelling and measurements of an extreme air pollution episode in the Moscow region. Atmos Chem Phys. 2011;11:10031-56. doi:10.5194/acp-11-10031-2011.

25. Brando PM, Balch JK, Nepstad DC, Morton DC, Putz FE, Coe MT, et al. Abrupt increases in Amazonian tree mortality due to drought-fire interactions. Proc Natl Acad Sci U S A. 2014;111: 6347-52. doi:10.1073/pnas.1305499111.

26. Williams AP, Seager R, Berkelhammer M, Macalady AK, Crimmins MA, Swetnam TW, et al. Causes and implications of extreme atmospheric moisture memand during the recordbreaking 2011 wildfire season in the southwest United States. J Appl Meteorol Climatol. 2014;53:2671-84. doi:10.1175/JAMCD-14-0053.1.

27. Williams AP, Seager R, Abatzoglou JT, Cook BI, Smerdon JE, Cook ER. Contribution of anthropogenic warming to California drought during 2012-2014. Geophys Res Lett. 2015;42:6819-28. doi:10.1002/2015GL064924.

28. Turetsky MR, Donahue WF, Benscoter BW. Experimental drying intensifies burning and carbon losses in a northern peatland. Nat Commun. 2011;2:514. doi:10.1038/ncomms1523.

29. Pyne SJ. Fire: Nature and Culture. London: Reaktion Books; 2012.

30. Pyne SJ. The fires this time, and next. Science. 2001;294:1005-6. doi:10.1126/science.1064989.

31. Moritz MA, Parisien MA, Batllori E, Krawchuk MA, Van Dorn J, Ganz DJ, et al. Climate change and disruptions to global fire activity. Ecosphere. 2012;3:1-22. doi:10.1890/ES11-00345.1. This study drives an empirically derived spatial model with projected climate data from 16 global climate models to project how macro-scale fire probability will compare during 2010-2039 and 2070-2099 to the observed record.

32. Krawchuk MA, Moritz MA, Parisien M-A, Van Dorn J, Hayhoe $\mathrm{K}$. Global pyrogeography: the current and future distribution of wildfire. PLoS ONE. 2009;4, e5102. doi:10.1371/journal.pone. 0005102

33. Davidson EA, de Araújo AC, Artaxo P, Balch JK, Brown IF, Bustamante MMC, et al. The Amazon basin in transition. Nature. 2012;481:321-8. doi:10.1038/nature10717.

34. Friedlingstein P, Meinshausen M, Arora VK, Jones CD, Anav A, Liddicoat SK, et al. Uncertainties in CMIP5 climate projections due to carbon cycle feedbacks. J Clim. 2014;27:511-26. doi:10. 1175/JCLI-D-12-00579.1.

35. Giglio L, Randerson JT, van der Werf GR, Kasibhatla PS, Collatz GJ, Morton DC, et al. Assessing variability and long-term trends in burned area by merging multiple satellite fire products. Biogeosciences. 2010;7:1171-86. doi:10.5194/bg-7-1171-2010.

36. Daniau AL, Bartlein PJ, Harrison SP, Prentice IC, Brewer S, Friedlingstein $\mathrm{P}$, et al. Predictability of biomass burning in 
response to climate changes. Glob Biogeochem Cycles. 2012;26, GB4007. doi:10.1029/2011GB004249/full.

37. Chuvieco E, Giglio L, Justice C. Global characterization of fire activity: toward defining fire regimes from Earth observation data. Glob Chang Biol. 2008;14:1488-502. doi:10.1111/j.1365-2486. 2008.01585.x.

38. Archibald S, Roy DP, van Wilgen BW, Scholes RJ. What limits fire? An examination of drivers of burnt area in Southern Africa. Glob Chang Biol. 2009;15:613-30. doi:10.1111/j.1365-2486. 2008.01754.x.

39. Fischer H, Schüpbach S, Gfeller G, Bigler M, Röthlisberger R, Erhardt T, et al. Millennial changes in North American wildfire and soil activity over the last glacial cycle. Nat Geosci. 2015;8: 723-7. doi:10.1038/ngeo2495.

40. Zennaro P, Kehrwald N, McConnell JR, Schüpbach S, Maselli OJ, Marlon J, et al. Fire in ice: two millennia of boreal forest fire history from the Greenland NEEM ice core. Clim Past. 2014;10: 1905-24. doi:10.5194/cp-10-1905-2014.

41. Zennaro P, Kehrwald N, Marlon J, Ruddiman W, Brücher T, Agostinelli C, et al. Europe on fire three thousand years ago: arson or climate? Geophys Res Lett. 2015;42:5023-33. doi:10.1002/ 2015GL064259.

42. van der Werf GR, Peters W, van Leeuwen TT, Giglio L. What could have caused pre-industrial biomass burning emissions to exceed current rates? Clim Past. 2013;9:289-306. doi:10.5194/ cp-9-289-2013.

43. Girardin MP, Ali AA, Carcaillet C, Blarquez O, Hély C, Terrier A, et al. Vegetation limits the impact of a warm climate on boreal wildfires. New Phytol. 2013;199:1001-11. doi:10.1111/nph. 12322.

44. Kelly R, Chipman ML, Higuera PE, Stefanova I, Brubaker LB, Hu FS. Recent burning of boreal forests exceeds fire regime limits of the past 10,000 years. Proc Natl Acad Sci U S A. 2013;110: 13055-60. doi:10.1073/pnas.1305069110.

45. Brown KJ, Giesecke T. Holocene fire disturbance in the boreal forest of central Sweden. Boreas. 2014;43:639-51. doi:10.1111/ bor. 12056 .

46. Blarquez O, Ali AA, Girardin MP, Grondin P, Fréchette B, Bergeron $\mathrm{Y}$, et al. Regional paleofire regimes affected by nonuniform climate, vegetation and human drivers. Nat Sci Rep. 2015;5:13356. doi:10.1038/srep13356.

47. Barrett CM, Kelly R, Higuera PE, Hu FS. Climatic and land cover influences on the spatiotemporal dynamics of Holocene boreal fire regimes. Ecology. 2013;94:389-402. doi:10.1890/12-0840.1.

48. Walsh MK, Marlon JR, Goring SJ, Brown KJ, Gavin DG. A regional perspective on holocene fire-climate-human interactions in the Pacific Northwest of North America. Ann Assoc Am Geogr. 2015;105:1135-57. doi:10.1080/00045608.2015.1064457.

49. Calder WJ, Parker D, Stopka CJ, Jiménez-Moreno G, Shuman BN. Medieval warming initiated exceptionally large wildfire outbreaks in the Rocky Mountains. Proc Natl Acad Sci U S A. 2015;112:13261-6. doi:10.1073/pnas.1500796112.

50. Power MJ, Mayle FE, Bartlein PJ, Marlon JR, Anderson RS, Behling $\mathrm{H}$, et al. Climatic control of the biomass-burning decline in the Americas after AD 1500. The Holocene. 2013;23:3-13. doi: 10.1177/0959683612450196.

51. Abrams MD, Nowacki GJ. Exploring the early Anthropocene burning hypothesis and climate-fire anomalies for the eastern US. J Sustain For. 2015;34:30-48. doi:10.1080/10549811.2014. 973605.

52. Williams AN, Mooney SD, Sisson SA, Marlon J. Exploring the relationship between Aboriginal population indices and fire in Australia over the last 20,000 years. Palaeogeogr Palaeoclimatol Palaeoecol. 2015;432:49-57. doi:10.1016/j.palaeo.2015.04.030.

53. Feurdean A, Spessa A, Magyari EK, Willis KJ, Veres D, Hickler $\mathrm{T}$. Trends in biomass burning in the Carpathian region over the last
15,000 years. Quat Sci Rev. 2012;45:111-25. doi:10.1016/j. quascirev.2012.04.001.

54. Krupinski NBQ, Marlon JR, Nishri A, Street JH, Paytan A. Climatic and human controls on the late Holocene fire history of northern Israel. Quat Res. 2013;80:396-405. doi:10.1016/j.yqres. 2013.06.012.

55. Ellis EC, Kaplan JO, Fuller DQ, Vavrus S, Goldewijk KK, Verburg PH. Used planet: a global history. Proc Natl Acad Sci U S A. 2013;110:7978-85. doi:10.1073/pnas.1217241110.

56. Arno SF, Sneck KM. A method for determining fire history in coniferous forests of the Mountain West. Ogden: USDA Forest Service; 1977.

57. Williams AP, Allen CD, Macalady AK, Griffin D, Woodhouse CA, Meko DM, et al. Temperature as a potent driver of regional forest drought stress and tree mortality. Nat Clim Chang. 2013;3: 292-7. doi:10.1038/nclimate1693.

58. Dugan AJ, Baker WL. Sequentially contingent fires, droughts and pluvials structured a historical dry forest landscape and suggest future contingencies. J Veg Sci. 2015;26:697-710. doi:10.1111/ jvs. 12266 .

59. Huffman DW, Zegler TJ, Fulé PZ. Fire history of a mixed conifer forest on the Mogollon Rim, northern Arizona, USA. Int J Wildland Fire. 2015;24:680-9. doi:10.1071/WF14005.

60. Margolis EQ, Swetnam TW. Historical fire-climate relationships of upper elevation fire regimes in the south-western United States. Int J Wildland Fire. 2013;22:588-98. doi:10.1071/WF12064.

61. Margolis EQ. Fire regime shift linked to increased forest density in a piñon-juniper savanna landscape. Int J Wildland Fire. 2014;23: 234-45. doi:10.1071/WF13053.

62. O'Connor CD, Falk DA, Lynch AM, Swetnam TW. Fire severity, size, and climate associations diverge from historical precedent along an ecological gradient in the Pinaleño Mountains, Arizona, USA. For Ecol Manag. 2014;329:264-78. doi:10.1016/j.foreco. 2014.06.032.

63. Swetnam TW, Falk DA, Sutherland EK, Brown PM, Brown TJ (2012) Final Report: Fire and Climate in the Western US: A New Synthesis for Land Management. Fire and Climate Synthesis Project. University of Arizona, Tucson, AZ.

64. Swetnam TW, Whitlock C. Ch. 3: Paleofire and Climate History: Western America and Global Perspectives. In: Goldammer JG, editor. Vegetation fires and global change: challenges for concerted international action. Germany: Kessel Publishing House; 2013. p. 21-38.

65. Bigio ER, Swetnam TW, Baisan CH. Local-scale and regional climate controls on historical fire regimes in the San Juan Mountains, Colorado. For Ecol Manag. 2016;360:311-22. doi: 10.1016/j.foreco.2015.10.041.

66. Trouet V, Taylor AH, Wahl ER, Skinner CN, Stephens SL. Fireclimate interactions in the American West since $1400 \mathrm{CE}$. Geophys Res Lett. 2010;37, L04702. doi:10.1029/ 2009GL041695.

67. Swetnam TW, Betancourt JL. Mesoscale disturbance and ecological response to decadal climatic variability in the American Southwest. J Clim. 1998;11:3128-47. doi:10.1175/15200442(1998)011<3128:MDAERT>2.0.CO;2.

68. Swetnam TW, Baisan CH. Tree-Ring Reconstructions of Fire and Climate History in the Sierra Nevada and Southwestern United States. In: Veblen TT, Baker WL, Montenegro G, Swetnam TW, editors. Fire and climatic change in temperate ecosystems of the western Americas. New York: Springer; 2003. p. 158-95.

69. Mundo IA, Kitzberger T, Juñent FAR, Villalba R, Barrera MD. Fire history in the Araucaria araucana forests of Argentina: human and climate influences. Int J Wildland Fire. 2013;22:194-206. doi: 10.1071/WF11164.

70. Swetnam TW, Baisan CH (1996) Historical fire regime patterns in the southwestern United States since AD 1700. In: Allen CD (ed) 
Fire Effects in Southwestern Fortest : Proceedings of the 2nd La Mesa Fire Symposium, vol General Technical Report RM-GTR286. USDA Forest Service, Rocky Mountain Research Station, pp $11-32$.

71. Pyne SJ. Between Two Fires: A Fire History of Contemporary America. Tucson: The University of Arizona Press; 2015.

72. Parks SA, Miller C, Parisien M-A, Holsinger LM, Dobrowski SZ, Abatzoglou J. Wildland fire deficit and surplus in the western United States, 1984-2012. Ecosphere. 2015;6:1-13. doi:10. 1890/ES15-00294.1.

73. Harris L, Taylor AH. Topography, fuels, and fire dxclusion drive fire severity of the Rim Fire in an old Growth mixed-conifer forest, Yosemite National Park, USA. Ecosystems. 2015;18:1192-208. doi:10.1007/s10021-015-9890-9.

74. Heyerdahl EK, Loehman RA, Falk DA. Mixed-severity fire in lodgepole pine dominated forests: are historical regimes sustainable on Oregon's Pumice Plateau, USA? Can J For Res. 2014;44: 593-603. doi:10.1139/cjfr-2013-0413.

75. Sibold JS, Veblen TT, González ME. Spatial and temporal variation in historic fire regimes in subalpine forests across the Colorado Front Range in Rocky Mountain National Park, Colorado, USA. J Biogeogr. 2006;33:631-47. doi:10.1111/j. 1365-2699.2005.01404.x.

76. Baker WL. Are high-severity fires burning at much higher rates recently than historically in dry-forest landscapes of the western USA? PLoS ONE. 2015;10, e0136147. doi:10.1371/journal.pone. 0136147.

77. Odion DC, Hanson CT, Arsenault A, Baker WL, DellaSala DA, Hutto RL, et al. Examining historical and current mixed-severity fire regimes in ponderosa pine and mixed-conifer forests of western North America. PLoS ONE. 2014;9, e87852. doi:10.1371/ journal.pone.0087852.

78. Seager R, Hooks A, Williams AP, Cook BI, Nakamura J, Henderson N. Climatology, variability and trends in United States vapor pressure deficit, an important fire-related meteorological quantity. J Appl Meteorol. 2015;54:1121-41. doi:10.1175/ JAMC-D-14-0321.1.

79. Girardin MP, Terrier A. Mitigating risks of future wildfires by management of the forest composition: an analysis of the offsetting potential through boreal Canada. Clim Chang. 2015;130: 587-601. doi:10.1007/s10584-015-1373-7.

80. Kharuk VI, Dvinskaya ML, Ranson KJ. Fire return intervals within the northern boundary of the larch forest in Central Siberia. Int J Wildland Fire. 2013;22:207-11. doi:10.1071/WF11181.

81. Héon J, Arseneault D, Parisien M-A. Resistance of the boreal forest to high burn rates. Proc Natl Acad Sci U S A. 2014;111: 13888-93. doi:10.1073/pnas.1409316111.

82. Koutsias N, Xanthopoulos G, Founda D, Xystrakis F, Nioti F, Pleniou M, et al. On the relationships between forest fires and weather conditions in Greece from long-term national observations (1894-2010). Int J Wildland Fire. 2013;22:493-507. doi: 10.1071/WF12003.

83. Kolden CA, Smith AMS, Abatzoglou JT. Limitations and utilisation of monitoring trends in burn severity products for assessing wildfire severity in the USA. Int $\mathrm{J}$ Wildland Fire. 2015;24:1023-8. doi:10.1071/WF15082.

84. Eidenshink J, Schwind B, Brewer K, Zhu Z, Quayle B, Howard S. A project for monitoring trends in burn severity. Fire Ecol. 2007;3: 3-21.

85. Short KC. A spatial database of wildfires in the United States, 1992-2011. Earth Syst Sci Data. 2014;6:1-27. doi:10.5194/essd6-1-2014.

86. Short KC. Sources and implications of bias and uncertainty in a century of US wildfire activity data. Int J Wildland Fire. 2015;24: 883-91. doi:10.1071/WF14190.
87. Dennison PE, Brewer SC, Arnold JD, Moritz MA. Large wildfire trends in the western United States, 1984-2011. Geophys Res Lett. 2015;41:2928-33. doi:10.1002/2014GL059576.

88. Williams AP, Seager R, Macalady AK, Berkelhammer M, Crimmins MA, Swetnam TW, et al. Correlations between components of the water balance and burned area reveal new insights for predicting fire activity in the southwest US. Int J Wildland Fire. 2015;24:14-26. doi:10.1071/WF14023.

89. Roy DP, Boschetti L, Justice CO, Ju J. The Collection 5 MODIS Burned Area Product-Global evaluation by comparison with the MODIS Active Fire Product. Remote Sens Environ. 2008;112: 3690-707. doi:10.1016/j.rse.2008.05.013.

90. Hanson CT, Odion DC. Is fire severity increasing in the Sierra Nevada, California, USA? Int J Wildland Fire. 2014;23:1-8. doi: 10.1071/WF13016.

91. Morton DC, Collatz GJ, Wang D, Randerson JT, Giglio L, Chen Y. Satellite-based assessment of climate controls on US burned area. Biogeosciences. 2013;10:247-60. doi:10.5194/bg-10-247-2013.

92. Westerling A, Brown T, Schoennagel T, Swetnam T, Turner M, Veblen T. Briefing: Climate and Wildfire in Western US Forests. In: Sample VA, Bixler RP, editors. Forest Conservation and Management in the Anthropocene: Conference Proceedings, RMRS-P-71. Fort Collins, CO: USDA Forest Service Rocky Mountain Research Station; 2014. p. 81-102.

93. Abatzoglou JT, Kolden CA. Relationships between climate and macroscale area burned in the western United States. Int J Wildland Fire. 2013;22:1003-20. doi:10.1071/WF13019.

94. Schwartz MW, Butt N, Dolanc CR, Holguin A, Moritz MA, North $\mathrm{MP}$, et al. Increasing elevation of fire in the Sierra Nevada and implications for forest change. Ecosphere. 2015;6:121. doi:10. 1890/ES15-00003.1.

95. Cansler CA, McKenzie D. Climate, fire size, and biophysical setting control fire severity and spatial pattern in the northern Cascade Range, USA. Ecol Appl. 2014;24:1037-56. doi:10. 1890/13-1077.1.

96. Riley KL, Abatzoglou JT, Grenfell IC, Klene AE, Heinsch FA. The relationship of large fire occurrence with drought and fire danger indices in the western USA, 1984-2008: the role of temporal scale. Int J Wildland Fire. 2013;22:894-909. doi:10.1071/ WF12149.

97. Yoon J-H, Wang S-Y, Gilles RR, Hipps L, Kravitz B, Rasch PJ. Extreme fire season in California: a glimpse into the future? [in "Explaining Extremes of 2014 from a Climate Perspective"]. Bull Am Meteorol Soc. 2015;96:S5-9.

98. Barbero R, Abatzoglou JT, Steel EA, Larkin NK. Modeling very large-fire occurrences over the continental United States from weather and climate forcing. Environ Res Lett. 2014;9:124009. doi:10.1088/1748-9326/9/12/124009.

99. Sedano F, Randerson JT. Multi-scale influence of vapor pressure deficit on fire ignition and spread in boreal forest ecosystems. Biogeosciences. 2014;11:3739-55. doi:10.5194/bg-11-37392014.

100. Stavros EN, Abatzoglou J, Larkin NK, McKenzie D, Steel EA. Climate and very large wildland fires in the contiguous Western USA. Int J Wildland Fire. 2014;23:899-914. doi:10.1071/ WF13169.

101. Barbero R, Abatzoglou JT, Kolden CA, Hegewisch KC, Larkin NK, Podschwit $\mathrm{H}$. Multi-scalar influence of weather and climate on very large-fires in the Eastern United States. Int J Climatol. 2014;35:2180-6. doi:10.1002/joc.4090.

102. Jolly WM, Cochrane MA, Freeborn PH, Holden ZA, Brown TJ, Williamson GJ, et al. Climate-induced variations in global wildfire danger from 1979 to 2013. Nat Commun. 2015;6:7537. doi:10. 1038 /ncomms 8537 . This study evaluates a global reanalysis of gridded meteorological data and finds a significant increase in 
the global vegetation area experiencing anomalously severe fire-weather in a given year during 1979-2013.

103. Urbieta IR, Zavala G, Bedia J, Gutiérrez JM, Miguel-Ayanz JS, Camia A, et al. Fire activity as a function of fire-weather seasonal severity and antecedent climate across spatial scales in southern Europe and Pacific western USA. Environ Res Lett. 2015;10: 114013. doi:10.1088/1748-9326/10/11/114013.

104. Lasslop G, Hantson S, Kloster S. Influence of wind speed on the global variability of burned fraction: a global fire model's perspective. Int J Wildland Fire. 2015;24:989-1000. doi:10.1071/ WF15052.

105. Diaz HF, Swetnam TW. The wildfires of 1910: climatology of an extreme early twentieth-century event and comparison with more recent extremes. Bull Am Meteorol Soc. 2013;94:1361-70. doi: 10.1175/BAMS-D-12-00150.1.

106. Clarke H, Lucas C, Smith P. Changes in Australian fire weather between 1973 and 2010. Int J Climatol. 2013;33:931-44. doi:10. 1002/joc.3480.

107. Higuera PE, Abatzoglou JT, Littell JS, Morgan P. The changing strength and nature of fire-climate relationships in the Northern Rocky Mountains, USA, 1902-2008. PLoS ONE. 2015;10, e0127563. doi: 10.1371 journal.pone.0127563. This study highlights the nonlinearity and complexities of climate-fire relationships using a century of observational data from the northern Rocky Mountains.

108. Pausas JG, Fernández-Muñoz S. Fire regime changes in the Western Mediterranean Basin: from fuel-limited to droughtdriven fire regime. Clim Chang. 2012;110:215-26. doi:10.1007/ s10584-011-0060-6.

109. Moritz MA, Morais ME, Summerell LA, Carlson JM, Doyle JC. Wildfires, complexity, and highly optimized tolerance. Proc Natl Acad Sci U S A. 2005;102:17912-7. doi:10.1073/pnas. 0508985102.

110. Parisien M-A, Moritz MA. Environmental controls on the distribution of wildfire at multiple spatial scales. Ecol Monogr. 2009;79:127-54. doi:10.1890/07-1289.1.

111. Krawchuk MA, Moritz MA. Burning issues: statistical analyses of global fire data to inform assessments of environmental change. Environmetrics. 2014;25:472-81. doi:10.1002/env.2287. This paper provides an excellent review of statistical modeling of global fire activity and needed next steps for research and application.

112. Krawchuk MA, Moritz MA. Constraints on global fire activity vary across a resource gradient. Ecology. 2011;92:121-32. doi: 10.1890/09-1843.1.

113. Pausas JG, Ribeiro E. The global fire-productivity relationship. Glob Ecol Biogeogr. 2013;22:728-36. doi:10.1111/geb.12043.

114. Pausas JG, Bradstock RA. Fire persistence traits of plants along a productivity and disturbance gradient in mediterranean shrublands of south-east Australia. Glob Ecol Biogeogr. 2007;16:330-40. doi: 10.1111/j.1466-8238.2006.00283.x.

115. Archibald S, Lehmann CER, Gómez-Dans JL, Bradstock RA. Defining pyromes and global syndromes of fire regimes. Proc Natl Acad Sci U S A. 2013;110:6442-7. doi:10.1073/pnas. 1211466110

116. McWethy DB, Higuera PE, Whitlock C, Veblen TT, Bowman DMJS, Cary GJ, et al. A conceptual framework for predicting temperate ecosystem sensitivity to human impacts on fire regimes. Glob Ecol Biogeogr. 2013;22:900-12. doi:10.1111/geb.12038.

117. Faivre N, Jin Y, Goulden ML, Randerson JT. Controls on the spatial pattern of wildfire ignitions in Southern California. Int $\mathrm{J}$ Wildland Fire. 2014;23:799-811. doi:10.1071/WF13136.

118. Hawbaker TJ, Radeloff VC, Stewart SI, Hammer RB, Keuler NS, Clayton MK. Human and biophysical influences on fire occurrence in the United States. Ecol Appl. 2013;23:565-82. doi:10. 1890/12-1816.1.
119. Hantson S, Pueyo S, Chuvieco E. Global fire size distribution is driven by human impact and climate. Glob Ecol Biogeogr. 2015;24:77-86. doi:10.1111/geb.12246.

120. Hantson S, Lasslop G, Kloster S, Chuvieco E. Anthropogenic effects on global mean fire size. Int J Wildland Fire. 2015;24: 589-96. doi:10.1071/WF14208.

121. Knorr W, Kaminski T, Arneth A, Weber U. Impact of human population density on fire frequency at the global scale. Biogeosciences. 2014;11:1085-102. doi:10.5194/bg-11-10852014.

122. Bistinas I, Harrison SP, Prentice IC, Pereira JM. Causal relationships versus emergent patterns in the global controls of fire frequency. Biogeosciences. 2014;11:5087-101. doi:10.5194/bg-115087-2014.

123. Finney MA, Cohen JD, Forthofer JM, McAllister SS, Gollner MJ, Gorham DJ, et al. Role of buoyant flame dynamics in wildfire spread. Proc Natl Acad Sci U S A. 2015;112:9833-8. doi:10. 1073/pnas.1504498112.

124. Hoffman CM, Canfield J, Linn RR, Mell W, Sieg CH, Pimont F, et al. Evaluating crown fire rate of spread predictions from physicsbased models. Fire Technol. 2015;1:1-17. doi:10.1007/s10694015-0500-3.

125. Hoffman CM, Linn R, Parsons R, Sieg C, Winterkamp J. Modeling spatial and temporal dynamics of wind flow and potential fire behavior following a mountain pine beetle outbreak in a lodgepole pine forest. Agric For Meteorol. 2015;204:79-93. doi: 10.1016/j.agrformet.2015.01.018.

126. Bradstock RA. A biogeographic model of fire regimes in Australia: current and future implications. Glob Ecol Biogeogr. 2010;19:145-58. doi:10.1111/j.1466-8238.2009.00512.x.

127. Flannigan M, Cantin AS, de Groot WJ, Wotton M, Newbery A, Gowman LM. Global wildland fire season severity in the $21 \mathrm{st}$ century. For Ecol Manag. 2013;294:54-61. doi:10.1016/j.foreco. 2012.10.022

128. Liu Y, Goodrick SL, Stanturf JA. Future US wildfire potential trends projected using a dynamically downscaled climate change scenario. For Ecol Manag. 2013;294:120-35. doi:10.1016/j. foreco.2012.06.049.

129. Luo L, Tang Y, Zhong S, Bian X, Heilman WE. Will future climate favor more erratic wildfires in the Western United States? J Appl Meteorol Climatol. 2013;52:2410-7. doi:10.1175/JAMC-D12-0317.1.

130. Stavros EN, Abatzoglou JT, McKenzie D, Larkin NK. Regional projections of the likelihood of very large wildland fires under a changing climate in the contiguous Western United States. Clim Chang. 2014;126:455-68. doi:10.1007/s10584-014-1229-6.

131. Yue X, Mickley LJ, Logan JA, Kaplan JO. Ensemble projections of wildfire activity and carbonaceous aerosol concentrations over the western United States in the mid-21st century. Atmos Environ. 2013;77:767-80. doi:10.1016/j.atmosenv.2013.06.003.

132. Yue X, Mickley LJ, Logan JA, Hudman RC, Val Martin M, Yantosca RM. Impact of 2050 climate change on North American wildfire: consequences for ozone air quality. Atmos Chem Phys. 2015;15:10033-55. doi:10.5194/acp-15-100332015.

133. Tian X, Zhao F, Shu L, Wang M. Changes in forest fire danger for south-western China in the 21 st century. Int J Wildland Fire. 2014;23:185-95. doi:10.1071/WF13014.

134. Barbero R, Abatzoglou JT, Larkin NK, Kolden CA, Stocks B. Climate change presents increased potential for very large fires in the contiguous United States. Int J Wildland Fire. 2015;24: 892-9. doi:10.1071/WF15083.

135. Westerling AL, Turner MG, Smithwick EAH, Romme WH, Ryan MG. Continued warming could transform Greater Yellowstone fire regimes by mid-21st century. Proc Natl Acad Sci U S A. 2011;108:13165-70. doi:10.1073/pnas.1110199108. 
136. Bedia J, Herrera S, Gutiérrez JM, Benali A, Brands S, Mota B, et al. Global patterns in the sensitivity of burned area to fire-weather: implications for climate change. Agric For Meteorol. 2015;214: 369-79. doi:10.1016/j.agrformet.2015.09.002.

137. Yue X, Mickley LJ, Logan JA. Projection of wildfire activity in southern California in the mid-twenty-first century. Clim Dyn. 2014;43:1973-91. doi:10.1007/s00382-013-2022-3.

138. Hurteau MD, Westerling AL, Wiedinmyer C, Bryant BP. Projected effects of climate and development on California wildfire emissions through 2100. Environ Sci Technol. 2014;48: 2298-304. doi:10.1021/es4050133.

139. Westerling AL, Bryant BP. Climate change and wildfire in California. Clim Chang. 2008;87:231-49. doi:10.1007/s10584007-9363-z.

140. Batllori E, Parisien MA, Krawchuk MA, Moritz MA. Climate change-induced shifts in fire for Mediterranean ecosystems. Glob Ecol Biogeogr. 2013;22:1118-29. doi:10.1111/geb.12065.

141. Balshi MS, McGuire AD, Duffy P, Flannigan M, Walsh J, Melillo $\mathrm{J}$. Assessing the response of area burned to changing climate in western boreal North America using a Multivariate Adaptive Regression Splines (MARS) approach. Glob Chang Biol. 2009;15:578-600. doi:10.1111/j.1365-2486.2008.01679.x.

142. Parisien M-A, Parks SA, Krawchuk MA, Little JM, Flannigan MD, Gowman LM, et al. An analysis of controls on fire activity in boreal Canada: comparing models built with different temporal resolutions. Ecol Appl. 2014;24:1341-56. doi:10.1890/13-1477.1. This study uniquely uses both spatial and temporal variability in observations to develop a burned area model for boreal Canada.

143. Hu FS, Higuera PE, Duffy P, Chipman ML, Rocha AV, Young AM, et al. Arctic tundra fires: natural variability and responses to climate change. Front Ecol Environ. 2015;13:369-77. doi:10. 1890/150063.

144. Johnstone JF, Hollingsworth TN, Chapin FS, Mack MC. Changes in fire regime break the legacy lock on successional trajectories in Alaskan boreal forest. Glob Chang Biol. 2010;16:1281-95. doi: 10.1111/j.1365-2486.2009.02051.x.

145. Parks SA, Holsinger LM, Miller C, Nelson CR. Wildland fire as a self-regulating mechanism: the role of previous burns and weather in limiting fire progression. Ecol Appl. 2015;25:1478-92. doi:10. 1890/14-1430.1.

146. Balch JK, Bradley BA, D’Antonio CM, Gómez-Dans J. Introduced annual grass increases regional fire activity across the arid western USA (1980-2009). Glob Chang Biol. 2013;19: 173-83. doi:10.1111/gcb.12046.

147. Boulanger Y, Gauthier S, Gray DR, Le Goff H, Lefort P, Morissette J. Fire regime zonation under current and future climate over eastern Canada. Ecol Appl. 2013;23:904-23. doi:10. 1890/12-0698.1.

148. Boulanger Y, Gauthier S, Burton PJ. A refinement of models projecting future Canadian fire regimes using homogeneous fire regime zones. Can J For Res. 2014;44:365-76. doi:10.1139/cjfr2013-0372.

149. Bowman DMJS, Murphy BP, Williamson GJ, Cochrane MA. Pyrogeographic models, feedbacks and the future of global fire regimes. Glob Ecol Biogeogr. 2014;23:821-4. doi:10.1111/geb. 12180.

150. Yang J, Tian H, Tao B, Ren W, Kush J, Liu Y, et al. Spatial and temporal patterns of global burned area in response to anthropogenic and environmental factors: reconstructing global fire history for the 20th and early 21 st centuries. J Geophys Res: Biogeosci. 2014;119:249-63. doi:10.1002/2013JG002532.

151. Yang J, Tian H, Tao B, Ren W, Lu C, Pan S, et al. Century-scale patterns and trends of global pyrogenic carbon emissions and fire influences on terrestrial carbon balance. Glob Biogeochem Cycles. 2015;29:1549-66. doi:10.1002/2015GB005160. This study models global fire area and emissions using a dynamic global vegetation model linked to a fire module to estimate the response of global fire activity to changes in climate, atmospheric $\mathrm{CO}_{2}$, and human demographics over the past 110 years.

152. Marlon JR, Bartlein PJ, Carcaillet C, Gavin DG, Harrison SP, Higuera PE, et al. Climate and human influences on global biomass burning over the past two millennia. Nat Geosci. 2008;1: 697-702. doi:10.1038/ngeo313.

153. Knorr W, Jiang L, Arneth A. Climate, $\mathrm{CO}_{2}$ and demographic impacts on global wildfire emissions. Biogeosciences. 2016;13:26782. doi:10.5194/bg-13-267-2016. This study uses global semiempirical fire modeling with a dynamic global vegetation model to tease apart the projected effects of 21 st century changes in climate, atmospheric $\mathrm{CO}_{2}$, and human population/demographics change.

154. Wu M, Knorr W, Thonicke K, Schurgers G, Camia A, Arneth A. Sensitivity of burned area in Europe to climate change, atmospheric $\mathrm{CO}_{2}$ levels and demography: a comparison of two fire-vegetation models. J Geophys Res: Biogeosci. 2015;120:2256-72. doi: 10.1002/2015JG003036.

155. Kelly R, Genet H, McGuire AD, Hu FS (2015) Palaeodatainformed modelling of large carbon losses from recent burning of boreal forests. Nature Climate Change:In press. doi:10.1038/ nclimate2832. This study used charcoal reconstructions of fire in Alaskan boreal forest to drive model simulations of carbon dynamics from AD 850-2006 and finds that fire was likely the dominant source of carbon-stock variability in boreal forests and that a recent increase in fire frequency since 1950 has led to large carbon losses

156. de Groot WJ, Flannigan MD, Cantin AS. Climate change impacts on future boreal fire regimes. For Ecol Manag. 2013;294:35-44. doi:10.1016/j.foreco.2012.09.027.

157. Murphy BP, Bowman DMJS. What controls the distribution of tropical forest and savanna? Ecol Lett. 2012;15:748-58. doi:10. 1111/j.1461-0248.2012.01771.x.

158. Randerson JT, Chen Y, Werf GR, Rogers BM, Morton DC. Global burned area and biomass burning emissions from small fires. J Geophys Res: Biogeosci. 2012;117, G04012. doi:10.1029/ 2012JG002128.

159. Farquhar GD. Carbon dioxide and vegetation. Science. 1997;278: 1411. doi:10.1126/science. 278.5342 .1411$.

160. Frank DC, Poulter B, Saurer M, Esper J, Huntingford C, Helle G, et al. Water-use efficiency and transpiration across European forests during the Anthropocene. Nat Clim Chang. 2015;5:579-83. doi:10.1038/nclimate2614.

161. De Kauwe MG, Medlyn BE, Zaehle S, Walker AP, Dietze MC, Hickler T, et al. Forest water use and water use efficiency at elevated $\mathrm{CO}_{2}$ : a model-data intercomparison at two contrasting temperate forest FACE sites. Glob Chang Biol. 2013;19:1759-79. doi: 10.1111/gcb.12164.

162. Roderick ML, Greve P, Farquhar GD. On the assessment of aridity with changes in atmospheric $\mathrm{CO}_{2}$. Water Resour Res. 2015;51: 5450-63. doi:10.1002/2015WR017031.

163. Allen CD, Breshears DD, McDowell NG. On underestimation of global vulnerability to tree mortality and forest die-off from hotter drought in the Anthropocene. Ecosphere. 2015;6:1-55. doi:10. 1890/ES15-00203.1

164. Zhang K, Kimball JS, Nemani RR, Running SW, Hong Y, Gourley JJ, et al. Vegetation greening and climate change promote multidecadal rises of global land evapotranspiration. Nat Scientif Rep. 2015;5:15956. doi:10.1038/srep15956.

165. Donohue RJ, Roderick ML, McVicar TR, Farquhar GD. Impact of $\mathrm{CO}_{2}$ fertilization on maximum foliage cover across the globe's warm, arid environments. Geophys Res Lett. 2013;40:3031-5. doi:10.1002/grl.50563. 
166. Ukkola AM, Prentice IC, Keenan TF, van Dijk AIJM, Viney NR, Myneni RB, et al. Reduced streamflow in water-stressed climates consistent with $\mathrm{CO}_{2}$ effects on vegetation. Nat Clim Chang. 2015. doi:10.1038/nclimate2831.

167. Xu C, Liu H, Williams AP, Yin Y, Wu X. Trends toward an earlier peak of the growing season in Northern Hemisphere mid-latitudes. Glob Chang Biol. 2016. doi:10.1111/gcb.13224.

168. Friend AD, Lucht W, Rademacher TT, Keribin R, Betts R, Cadule $\mathrm{P}$, et al. Carbon residence time dominates uncertainty in terrestrial vegetation responses to future climate and atmospheric $\mathrm{CO}_{2}$. Proc Natl Acad Sci U S A. 2014;111:3280-5. doi:10.1073/pnas. 1222477110.

169. Anderegg WRL, Hicke JA, Fisher RA, Allen CD, Aukema J, Bentz B, et al. Tree mortality from drought, insects, and their interactions in a changing climate. New Phytol. 2015;208:67483. doi:10.1111/nph.13477.

170. McDowell NG, Fischer RA, Xu C, Domec JC, Hölttä T, Mackay DS, et al. Evaluating theories of drouht-induced vegetation mortality using a multimodel-experiment framework. New Phytol. 2013;200:304-21. doi:10.1111/nph.12465.

171. Keenan TF, Baker I, Barr A, Ciais P, Davis K, Dietze M, et al. Terrestrial biosphere model performance for inter-annual variability of land-atmosphere $\mathrm{CO}_{2}$ exchange. Glob Chang Biol. 2012;18: 1971-87. doi:10.1111/j.1365-2486.2012.02678.x.

172. Li F, Levis S, Ward DS. Quantifying the role of fire in the Earth system-Part 1: improved global fire modeling in the Community Earth System Model (CESM1). Biogeosciences. 2013;10:2293314. doi:10.5194/bg-10-2293-2013.

173. Schweizer VJ, O'Neill BC. Systematic construction of global socioeconomic pathways using internally consistent element combinations. Clim Chang. 2014;122:431-45. doi:10.1007/s10584013-0908-z.
174. Randers J. 2015: A Global Forecast for the Next Forty Years. White River Junction: Chelsea Green Publishing; 2012.

175. van Vuuren DP, Edmonds J, Kainuma M, Riahi K, Thomson A, Hibbard K, et al. The representative concentration pathways: an overview. Clim Chang. 2011;109:5-31. doi:10.1007/s10584-0110148-z.

176. Knutti R, Sedláček J. Robustness and uncertainties in the new CMIP5 climate model projections. Nat Clim Chang. 2013;3: 369-73. doi:10.1038/nclimate1716.

177. Zhang X, Liu H, Zhang M. Double ITCZ in coupled ocean-atmosphere models: from CMIP3 to CMIP5. Geophys Res Lett. 2015;42:8651-9. doi:10.1002/2015GL065973.

178. Romps DM, Seeley JT, Vollaro D, Molinari J. Projected increase in lightning strikes in the United States due to global warming. Science. 2014;346:851-4. doi:10.1126/science. 1259100.

179. Pfeiffer M, Spessa A, Kaplan JO. A model for global biomass burning in preindustrial time: LPJ-LMfire (v1.0). Geosci Model Dev. 2013;6:643-85. doi:10.5194/gmd-6-643-2013.

180. Magi BI. Global lightning parameterization from CMIP5 climate model output. J Atmos Ocean Technol. 2015;32:434-52. doi:10. 1175/JTECH-D-13-00261.1.

181. Allen DJ, Pickering KE. Evaluation of lightning flash rate parameterizations for use in a global chemical transport model. J Geophys Res: Atmos. 2002;107, ACH 15-11-21. doi:10.1029/ 2002JD002066.

182. Price C, Rind D. A simple lightning parameterization for calculating global lightning distributions. J Geophys Res: Atmos. 1992;97:9919-33. doi:10.1029/92JD00719.

183. Holtslag AAM, Svensson G, Baas P, Basu S, Beare B, Beljaars $\mathrm{ACM}$, et al. Stable atmospheric boundary layers and diurnal cycles: challenges for weather and climate models. Bull Am Meteorol Soc. 2013;94:1691-706. doi:10.1175/BAMS-D-1100187.1. 